\title{
Association of gene polymorphism and serum levels of IL-12p40 with the susceptibility to non-Hodgkin's Iymphoma in Iraq
}

\author{
Hassan Mohammad Naif
}

Department of Molecular and Medical Biotechnology, College of Biotechnology, Al-Nahrain University, Aljadriya, Baghdad, Iraq

Correspondence to: Hassan Mohammad Naif (e-mail: drnaifhassan@gmail.com).

(Submitted: 27 August 2017 - Revised version received: 02 September 2017 - Accepted: 11 October 2017 - Published online: 26 December 2017)

\begin{abstract}
Objective Non-Hodgkin lymphomas are a diverse lymphoid neoplasms and it is the sixth most common cancer in the world, but it is well established that immune dysregulation especially by cytokines is one of major risk factors. This study investigates the association of genetic polymorphisms of IL-12p401188A/C and its circulating serum measurement in patients with advanced stage of NHLs in Iraq.

Methods Fifty-five confirmed patients with advanced stages of NHLs and 40 apparently healthy individuals were used. Genetic polymorphism and circulating levels of IL-12p40 were examined by allele-specific polymerase chain reaction (AS-PCR) using specific primers and ELISA, respectively.

Results The results of SNP IL-12p40 1188A >C had three genotypes, which were AA, AC and CC. These genotypes represented $32.73 \%$, $38.18 \%$ and $29.09 \%$, respectively, among NHL patients and $52.5 \%, 37.5 \%$ and $10 \%$, respectively, among controls with a significant difference for the homozygous mutant genotype $(\mathrm{OR}=4.667,95 \% \mathrm{Cl}=1.319-16.512, P=0.017)$. Serum levels of IL-12p40 were significantly increased in an allele-dependent manner, which was linked to the CC homozygosity as being the highest.

Conclusions This study has revealed a significant correlation between the gene polymorphisms of IL-12p40 and the induction of serum $\mathrm{IL}-12$ with the risk to poor prognosis in patients with NHL. The correlation with the NHL grades and the prognostic value warrant further progressive investigation of developing prognostic biomarkers for NHL using patients at various disease stages.

Keywords non-Hodgkin's lymphoma, single nucleotide polymorphism, IL-12, allele-specific PCR
\end{abstract}

\section{Introduction}

Non-Hodgkin lymphomas are a diverse group of mature lymphoid neoplasms with a wide range of cellular, histologic presentations, cells of origin and etiologies. ${ }^{1}$ Numerous environmental and genetic factors have been documented to be associated with the incidence of NHLs, however the exact causes are beyond the current knowledge. ${ }^{2}$ Regardless of causes, the integrity of the immune system represents the cornerstone in the resistance or progression of the disease. Many disorders of this system such as immune deficiency and autoimmune disease like rheumatoid arthritis and systemic lupus erythematosus are reported to predispose to NHLs. ${ }^{3}$

Interleukin-12 (IL-12) is among the main proinflammatory cytokines of the immune system. IL-12 is a multifunctional cytokine acting as a key regulator by inducing and maintaining T helper 1, which bridges innate and adaptive immunity, ${ }^{4}$ and mediates immune response in several types of cancers, ${ }^{5,6}$ and its p70 subunit is associated with NHL. ${ }^{7}$ It is a heterodimeric proinflammatory cytokine formed by a 35,000-dalton light (p35) and a 40,000-dalton heavy chain (p40), which are encoded by the IL-12A and IL-12B genes, respectively, and mapped to human chromosomes 3p12-q13.2 and 5q31-33. ${ }^{8}$ IL-p40 (IL-12B) encodes the p40 subunit of both pathways of IL-12 and IL-23. ${ }^{9}$ The inherited variations in IL-12p40 and IL-12p70 genes that could modulate cancer susceptibility, and as a consequence possess predictive, therapeutic or prognostic implications. ${ }^{10}$ Following the discovery of IL-12, three other members (IL-23, IL-27, and IL-35) have been added to the IL-12 family and shown to play critical roles in Th1 cell functions. ${ }^{11,12}$
Several single nucleotide polymorphisms have been identified in the IL-12 gene such as 3'UTR 1188 A/C polymorphism, which is associated with different diseases. Several polymorphisms have been described in the promoter region, ${ }^{13}$ and in the 3' untranslated region (UTR) of IL-12 p40 gene, IL-12B. ${ }^{14}$ In this study, we hypothesized that potential functional polymorphisms IL-12p40 may contribute to risk of NHL in population from Iraq. Hence, SNPs in IL-12p40 gene was examined to assess its effect on the susceptibility to NHLs.

\section{Materials and Methods}

\section{Study Subjects}

This case control study included 55 patients with confirmed NHLs during the period from January 2015 to December 2015 from six teaching hospitals and medical centers in Baghdad Medical City (Teaching Hospital of Pediatric, Baghdad teaching Hospital and Hematology Center, Al-Mustansiriya University, Al-Kadhimyia Teaching Hospital). Family unrelated, apparently healthy 35 individuals were randomly selected to represent the control group. The mean ages of patients and control were 33.45 and 36.49 years, respectively. The stage of NHL disease of those recruited patients was mainly at the advanced stage of disease, so results will indicate this stage as such with no treatment history. This research was approved by the Ethics Committee of Scientific Research of the University. An informed consent to take part in the study was obtained from each participant after receiving approval of the experimental protocol by the Ethics Committee, which was essentially in line with the principles of the Declaration of Helsinki. 


\section{DNA Extraction and Genotyping}

Three $\mathrm{ml}$ of venous blood was collected from each participant in EDTA tube. DNA was extracted from blood samples using ready kit (gSYNC ${ }^{\mathrm{TM}}$ DNA Mini Kit Whole Blood Protocol, Geneaid, Korea) according to the manufacturer's instructions. Primers used for both genes are shown in Table 1. PCR conditions for IL-12p40 gene were an initial denaturation for $5 \mathrm{~min}$ at $95^{\circ} \mathrm{C}$, followed by 30 cycles of denaturation at $94^{\circ} \mathrm{C}$ for $30 \mathrm{~s}$, annealing at $61^{\circ} \mathrm{C}$ for $30 \mathrm{~s}$ and extension at $72^{\circ} \mathrm{C}$ for $1 \mathrm{~min}$, and final extension at $72^{\circ} \mathrm{C}$ for $7 \mathrm{~min}$. The primers of Toll-like receptor (TLR2) were used as an internal control in the amplification of IL-12p40 gene.

A ready $50 \mu \mathrm{l}$ PCR master mix (Bioneer, Korea) was used for amplification for IL-12p40 gene. Template DNA $(10 \mu \mathrm{l})$ from each sample and primers ( $5 \mu \mathrm{l}$ from each) was added to each master mix tube. After mixing, the master mix tubes were transferred to the thermocycler (MyGenie 32 thermal block, Bioneer, Korea) which is previously programmed with the above protocol according to the gene to be amplified. The amplified products were determined by comparison with a commercial 1000 bp ladder (Kappa Biosystem, USA).

\section{Statistical Analysis}

The Statistical Package for the Social sciences (SPSS, version 14) was used for statistical analysis. The risk association between the genotype and NHLs susceptibility was estimated by the calculation of the adjusted odd ratio and 95\% confidence intervals using bivariate logistic regression. For this analysis, subjects who were homozygous for the wild type allele were considered as a reference, and polymorphisms as dependent variables. Chi square test $\left(\chi^{2}\right)$ was used to determine the significant difference between each two alleles. A $P$-value $<0.05$ was considered statistically significant.

\section{Results}

\section{Detection of IL-12p40 Polymorphism by Using Allele-Specific PCR}

This study investigated the association of IL-12p40 1188A/C polymorphism with an incidence of NHL in patients and controls. A total of $55 \mathrm{NHL}$ patients and 40 apparently healthy control individuals were recruited for this purpose.

Results of allele-specific PCR for the SNP IL-12p40 $1188 \mathrm{~A} / \mathrm{C}$ in NHL patients and controls revealed specific amplification of $780 \mathrm{bp}$ together with $254 \mathrm{bp}$ of the internal control (Fig. 1).

IL-12p40 1188A/C had three genotypes which were AA, $\mathrm{AC}$ and CC. These genotypes represented $32.37 \%, 38.18 \%$ and $29.09 \%$, respectively, in NHL patients and $52.5 \%, 37.5 \%$ and $10 \%$, respectively, among controls. A significant difference for the homozygous mutant genotype CC $(\mathrm{OR}=4.667,95 \% \mathrm{CI}=$ $1.319-16.512, P=0.017)$. At allelic level, the frequency of C allele in NHL patient was $48.18 \%$ compared with $28.75 \%$ in controls with significant difference $(\mathrm{OR}=2.304,95 \% \mathrm{CI}=$ 1.250-4.249) (Table 2).

\section{IL-12p40 Levels in NHL patients and controls}

In regard to IL-12 production in this study, Figure 2 shows the mean serum levels of IL-12p40 in NHL patients and controls. NHL patients produced higher levels of IL-12p40

\begin{tabular}{|c|c|c|c|}
\hline Gene & Primers $5^{\prime} \rightarrow 3^{\prime}$ & Amplicon & Reference \\
\hline IL-12p40 & $\begin{array}{l}\text { Consensus F: ATCTTGGAGCGAATGGGCAT } \\
\text { R1: TTGTTTCAATGAGCATTTAGCATCT } \\
\text { R2: GTTTCAATGAGCATTTAGCATCG }\end{array}$ & $780 \mathrm{bp}$ & {$[15]$} \\
\hline $\begin{array}{l}\text { TLR2 } \\
\text { (internal } \\
\text { control) }\end{array}$ & $\begin{array}{l}\text { F: CCTGGCAAGTGGACCATTGAC } \\
\text { R: GGCCACTCCAGGTAGGTCTT }\end{array}$ & $254 \mathrm{bp}$ & [16] \\
\hline
\end{tabular}

$\mathrm{F}$, forward primers set; and $\mathrm{R}$, reverse primer pairs; $T L R$, toll-like receptor.

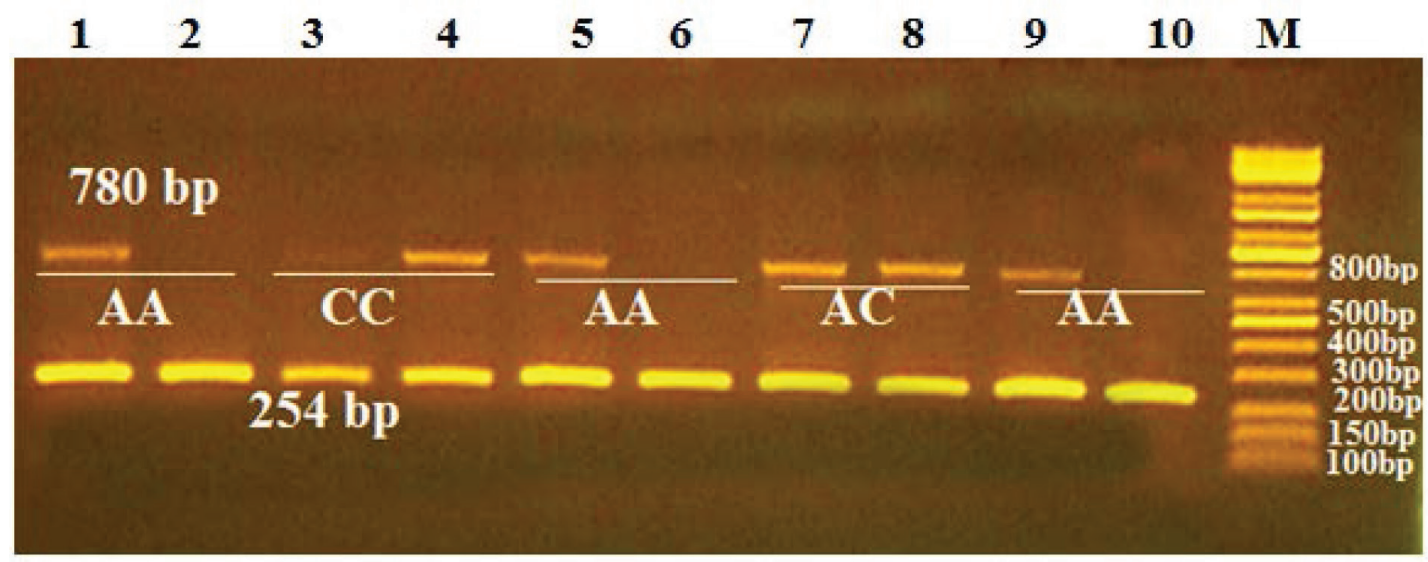

Fig. 1 Genotyping of IL-12p40 1188A/C allele's distribution in patients with NHL by using allele-specific (AS)-PCR. Gel electrophoresis and detection method were as described for Figure 3-1. M: 100 bp DNA marker. The 780 bp represents the amplification of IL-12p40 1188A/C, while the 254 bp represents the amplification of TLR2 gene as an internal control. The IL-12p40 A/C run side-by-side on the gel and the lanes order for IL-12p40 A are 1, 3, 5, 7, and 9 whereas IL-12p40 C alleles are run in lanes 2, 4, 6, 8, and 10. 
$(156.44 \pm 54.188 \mathrm{pg} / \mathrm{ml})$ than the control group $(107.34 \pm$ $56.957 \mathrm{pg} / \mathrm{ml})$ with a significant difference $(t=4.136, P=0.001$ (Fig. 2).

Analysis of the correlation of serum levels of IL-12p40 among the three genotypes (AA, AC and CC) in NHL patients revealed that CC genotype carriers had higher levels of IL-12p40 $(119.51 \pm 55.678 \mathrm{pg} / \mathrm{ml})$ than either AC genotype carriers $(138.68 \pm 63.102 \mathrm{pg} / \mathrm{ml})$ or AA genotype carriers $(155.35 \pm 61.877 \mathrm{pg} / \mathrm{ml})$ with significant differences between $\mathrm{CC}$ and AA genotype $(P=0.04)$ (Fig. 3).

\begin{tabular}{|c|c|c|c|c|}
\hline Variables & Cases $N=55$ & Control $N=40$ & $P$-value & OR (95\% Cl) \\
\hline $\begin{array}{l}\text { IL-12p401188A/C } \\
\text { AA } \\
\text { AC } \\
\text { CC }\end{array}$ & $\begin{array}{l}18(32.73 \%) \\
21(38.18 \%) \\
16(29.09 \%)\end{array}$ & $\begin{array}{l}21(52.5 \%) \\
15(37.5 \%) \\
4(10 \%)\end{array}$ & $\begin{array}{l}0.056 \\
0.293 \\
0.017\end{array}$ & $\begin{array}{c}1.0 \\
1.633(0.655-4.074) \\
4.667(1.319-16.512)\end{array}$ \\
\hline $\begin{array}{l}\text { Alleles } \\
\text { A } \\
\text { C }\end{array}$ & $\begin{array}{l}57(51.82 \%) \\
53(48.18 \%)\end{array}$ & $\begin{array}{l}57(71.25 \%) \\
23(28.75 \%)\end{array}$ & 0.007 & $\begin{array}{c}1.0 \\
2.304(1.250-4.249)\end{array}$ \\
\hline
\end{tabular}

$\mathrm{N}$, total number; $\mathrm{OR}$, odds ratio; $\mathrm{Cl}$, confidence interval; p, probability.

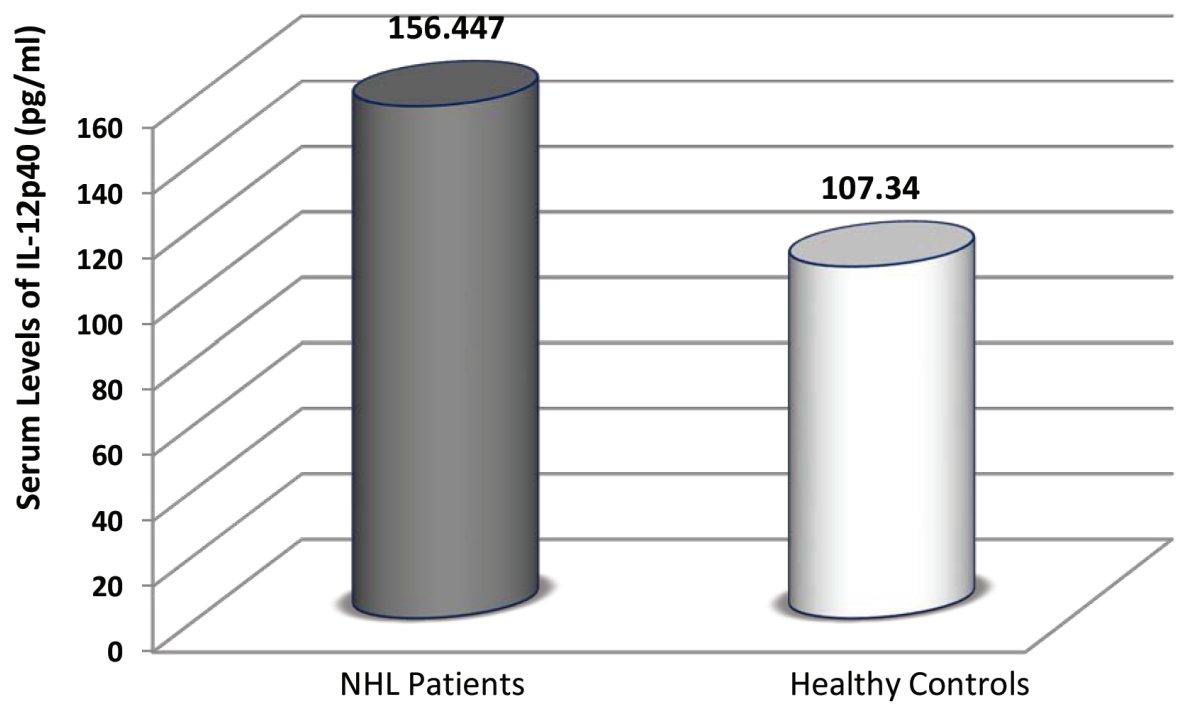

Subjects

Fig. 2 Levels of IL-12p40 in the sera of NHL patients and controls as measured by an ELISA kit.

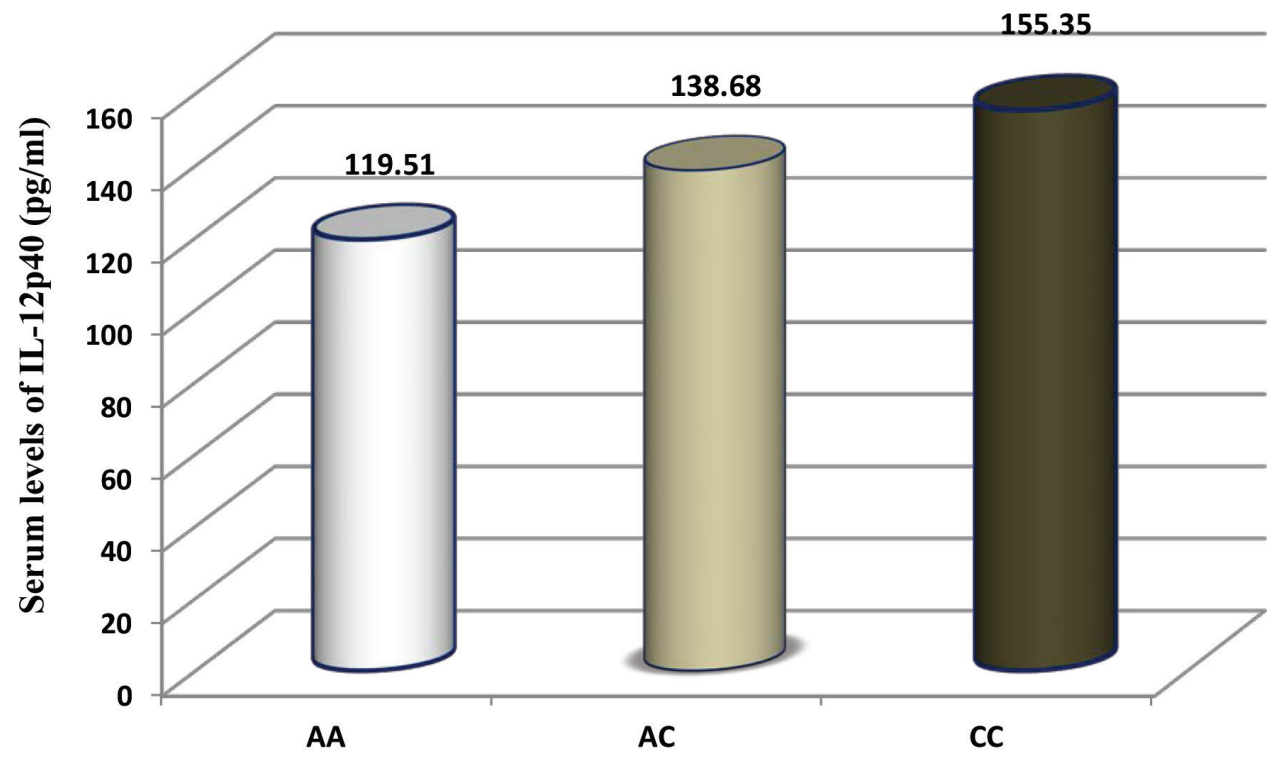

IL-12p40 Genotypes
Fig. 3 The relationship between the levels of IL-12p40 and the three genotypes: $A A, A C$ and $C C$ of the SNP IL-12p40 1188A/C. 


\section{Discussion}

The current cross-sectional study revealed that the SNP of IL-12p40 1188A/C (rs3212227) had three genotypes: AA, AC and CC. Both AC and CC genotypes were associated with a significant increased risk to NHL in studied patients at advanced stage of disease compared to healthy controls. The mean circulating serum levels of IL-12p40 in NHL patients had significantly higher levels than the control group. This elevation was linked with the CC homozygosity as being the highest inducer, and AA was the lowest.

IL-12 has a pleotropic activities where it plays an important role to induce Th1 immune response, ${ }^{17}$ and cancer immunotherapy. ${ }^{18,19}$ It also can stimulate IFN-gamma production, activation of cytotoxic $\mathrm{T}$ and natural killer cells, and impairs angiogenesis in tumours. ${ }^{5}$ It can suppress tumour development due to induction of apoptosis in cancerous cells. ${ }^{20}$ IL-12 therapy increased the median number of circulating CD8 T lymphocytes in patients with relapsed NHL. ${ }^{21}$

In the present study, The SNP IL-12p40 1188AC/CC genotypes were associated significantly with an increased risk of NHL patients in Iraq population. There is a general consensus that AC/CC genotypes are associated with an increased risk to overall cancer development. This was exemplified by similar association between the C allele of IL-12p40 $1188 \mathrm{~A} / \mathrm{C}$ polymorphism and bladder cancer, ${ }^{22}$ cervical cancer, ${ }^{23}$ nasopharangeal carcinoma, ${ }^{24,25}$ and esophageal cancer. ${ }^{26}$ Notably, the $1188 \mathrm{~A} / \mathrm{C}$ polymorphism is also implicated in an increased risk for psoriasis and soriatic arthritis as well as type 2 diabetes susceptibility. ${ }^{27}$ It has been found that IL-12p40 of the circulating serum cytokines were significantly associated with FL and/or DLBCL. ${ }^{28}$ On the contrary, the serum IL-12p40 levels were significantly higher in controls than those in osteosarcoma patients with genotype CC and $\mathrm{AC} / \mathrm{CC}$ were associated with the risk of osteosarcoma. ${ }^{29}$ Furthermore, 1188A variant was shown to be correlated with reduced levels of IL-12p40 subunit of IL-12, while $1188 \mathrm{C}$ variant associated with increase this subunit of the cytokine, ${ }^{30,31}$ which is similar to the finding of the present study. However, several analyses indicated that the $\mathrm{C}$ allele could lead to a decrease in the expression of IL-12p40, which consequently results in a lack of IL-12 protein. ${ }^{22,32,33}$ On the other hand, the results of this study are inconsistent with a previous study, ${ }^{34}$ where the A allele was found but not $\mathrm{C}$ to be associated with different cancers including the NHL and in TB infected patients, ${ }^{35}$ that resulted in lower plasma levels of IL-12 in normal control rather than in TB infected patients. Thus, it is expected there will be an increase of IL-12 associated CC genotype resulting in robust cell-mediated immune response, as with the current result that revealed a strong relationship C allele with high levels of IL-12 which was more prevalent in NHLs patients than in healthy controls.

The significance of IL-12p40 subunit in CC genotype carriers compared with either AC genotype carriers or AA genotype carriers indicates that the variant IL-12p40 1188C causes an increase in the production of this subunit in an allele-dependent manner, as clearly demonstrated by this study where the NHL patients with homozygous mutant genotype (CC) had the highest level of IL-12p40 subunit and have graded down with the heterozygous genotype (AC), to the lowest with the homozygous wild genotype (AA).
Whether this elevation can be attributed to the effective role of IL-12 alone as anti-tumour therapeutic, , ${ }^{10,36}$ is still not well understood considering the complex nature of other activities of the immune system in cancers in general and NHLs in particular. With respect to the elevation of IL-12 and its association with C allele, this issue is still controversial. It gets more complicated when the elevation of total IL-12 levels was seen in lymph nodes tissue microenvironment, ${ }^{37}$ whether this overproduction includes IL12p40 is not yet clear.

The discrepancy is that the increased production of IL-12 does not mean that IL-12p70 is overproduced. The induction rather involves only the IL-p40 subunit. The homodimers of this subunit antagonizes IL-12p70 activity by binding to the $\beta 1$ subunit of the IL-12 receptor. ${ }^{38}$ Therefore, the increased production of this subunit, in fact, causes reduction in the activity of IL-12 and hence reduces the efficiency of cell-mediated response and increases the susceptibility to the malignancy. The SNP IL-12p40 1188A/C is located in the 3'UTR of the gene. ${ }^{39}$ This region although does not encode for a protein, it can influence the amount of translated protein through other mechanisms including effects on mRNA stability or on transcriptional activity. ${ }^{40}$ Thus the SNP affects the gene silences and could regulate the level of IL-12p40 mRNA expression. ${ }^{41}$ Moreover, there was no association between the IL-12p40 promoter genotypes and the severity of psoriasis was found. ${ }^{42}$ This SNP is linked to the susceptibility to psoriasis and specifically accompanied by the overproduction of IL-12p40, which suggests that IL-12p40 may act as a proinflammatory mediator. However, such effect is more likely not to be attributed only to mutant IL-12p40 rather than to be multifactorial and is warranted further analysis.

There are other heterodimeric cytokines in addition to IL-12p40, such as IL-23, IL-27, and IL-35, whose subunits consist of either or both the IL-12 p35 and p40 chains. ${ }^{43}$ Its high affinity to IL-23 receptor and hence abolish IL-23 role in immune response. ${ }^{44,45}$ The main role of IL-23 involves the stimulation of Th17 cells to produce IL-17, ${ }^{38}$ which has an important role in the immunity against NHL. ${ }^{46}$ Therefore, specific therapeutic antibodies for either IL-12 subunits may lead to the dysfunction of several cytokines during therapy. ${ }^{21}$ Similarly, inherited variations of IL-12 genes (particularly, functional SNPs) may dramatically alter the expression and/or protein structure of more than one cytokine. However, IL-12 therapy in NHL patients warrants further careful investigation of the drug candidates. It is important to note that the high levels of IL-12p40 were commonly seen in patients with a good prognosis, ${ }^{47-49}$ therefore it is suggested to serve as a tumour progression and/or prognostic marker. The latter aligned well the current study where the level of circulating IL-12p40 combined with its genetic polymorphisms can efficiently serve as a good prognostic marker. This conclusion needs further analysis after addressing the limitations of this study. There are two caveats in this study. First, patients recruited were from an advanced stage of NHL, so results won't reflect disease stages/progression. Second, there were no results available on the pre-diagnosis cytokine levels of those patients. Therefore, these limitations will be warranted by designing a larger scale additional investigations to precisely define the correlation between genetic polymorphism, cytokine levels with NHL outcomes and subtyping. On the other hand, the genetic variants of IL-12p40 may or may not 
have relationship with the fact that the tumour develops metastasis which may suggest its role, if any, in initiation the cause rather than a consequence of metastasis. ${ }^{50}$

\section{Conclusion}

The SNP of IL-12p40 1188A/C had three genotypes: AA, AC and CC. Both AC and CC genotypes of the SNP IL-12p40 $1188 \mathrm{~A} / \mathrm{C}$ were associated with a significantly increased risk to NHLs among Iraqi patients. The allele frequency distribution was also correlated with an overproduction of circulating IL-12p40 reaching its maximum levels with the CC mutant homozygosity in patients with advanced stage of NHL. Taken together, the results strongly suggest that the allele $\mathrm{C}$ of the SNP IL-12p40 1188A/C may serve as a contributing risk factor for poor prognosis in patients with NHL.

The correlation with the NHL grades and the prognostic value warrant further progressive investigation of developing prognostic biomarkers for NHL using patients at various disease stages.

\section{Acknowledgements}

The author would like to thank Ms. Mayasah Ali for her technical assistance and Dr. Qasim Sherhan for manuscript comments and data analyses.

\section{References}

1. Kim AS. Molecular aspects of non-Hodgkin lymphomas. In: Greer JP, Arber DA, Glader B, List AF, Means RT, Paraskevas F, Rodgers GM and Foerster J. (eds.). Wintrobe's Clinical Hematology. 13th ed. Lippincott Williams and Wilkins, Philadelphia. 2014;1801.

2. Hartge P, Smith MT. Environmental and behavioral factors and the risk of non-Hodgkin lymphoma. Cancer Epidemiol Biomarkers Prev. 2007;16: 367-368.

3. Grulich AE, Vajdic CM, Cozen W. Altered immunity as a risk factor for nonHodgkin lymphoma. Cancer Epidemiol Biomarkers Prev. 2007;16:405-408.

4. Trinchieri G. Interleukin-12 and the regulation of innate resistance and adaptive immunity. Nat Rev Immunol. 2003;3:133-146.

5. Del Vecchio M, Bajetta E, Canova S, Lotze MT, Wesa A, Parmiani G, et al. Interleukin-12: biological properties and clinical application. Clin Cancer Res. 2007:13:4677-4685.

6. Chang SW, Xu GQ, Fan YL. Association of interleukin-12 gene polymorphisms with cancer susceptibility: a meta-analysis. Int J Clin Exp Med. 2015:8:5317-5322.

7. Rabkin CS, Engels EA, Landgren O, Schuurman R, Camargo MC, Ruth Pfeiffer, et al. Circulating cytokine levels, Epstein-Barr viremia, and risk of acquired immunodeficiency syndrome-related non-Hodgkin lymphoma. Am J Hematol. 2011;86:875-878.

8. Gately MK, Renzetti LM, Magram J, Stern AS, Luciano Adorini L, Gubler U, et al. The interleukin-12/interleukin-12-receptor system: Role in normal and pathologic immune responses. Annual Review Immunol. 1998;16:495-521.

9. Zheng HF, Zuo XB, Lu WS, Li Y, Cheng H, Zhu KJ, et al. Variants in MHC, LCE and IL12B have epistatic effects on psoriasis risk in Chinese population. J Dermatol Sci. 2011;61:124-128.

10. Lasek W, Zagożdżon R, Jakobisiak M. Interleukin 12: still a promising candidate for tumor immunotherapy? Cancer Immunol Immunother. 2014:63:419-435.

11. Hamza T, Barnett JB, Li B. Interleukin 12 a key immunoregulatory cytokine in infection applications. Int J Mol Sci 2010;11:789-806.

12. Vignali DA, Kuchroo VK. IL-12 family cytokines: immunological playmakers. Nat Immunol. 2012;13:722-728.

13. Morahan G, Huang D, Wu M, Holt BJ, White GP, Kendall GE, et al. Association of IL12B promoter polymorphism with severity of atopic and non-atopic asthma in children. Lancet. 2002:360:455-459.

14. Huang D, Cancilla MR, Morahan G. Complete primary structure, chromosomal localisation, and definition of polymorphisms of the gene encoding the human interleukin-12 p40 subunit. Genes Immun. 2000;1:515-520

15. Latsi P, Pantelidis P, Vassilakis D, Sato H, Welsh Kl, du Bois RM. Analysis of IL-12 p40 subunit gene and IFN-gamma G5644A polymorphisms in Idiopathic Pulmonary Fibrosis. Respir Res. 2003:4:6

16. Chen L, Lin MJ, Zhan LL, Lv XP. Analysis of TLR4 and TLR2 polymorphisms in inflammatory bowel disease in a Guangxi Zhuang population. World J Gastroenterol. 2012;18:6856-6860.

17. Becskei A, Grusby MJ. Contribution of IL-12R mediated feedback loop to Th cell differentiation. FEBS Lett. 2007;581:5199-5206.

18. Zabala M, Lasarte JJ, Perret C, Sola J, Berraondo P, Alfaro M, et al. Induction of immunosuppressive molecules and regulatory $T$ cells counteracts the antitumor effect of interleukin-12-based gene therapy in a transgenic mouse model of liver cancer. J Hepatology. 2007:47:807-815.

19. Yuzhalin AE, Kutikhin AG. Interleukin-12: clinical usage and molecular markers of cancer susceptibility. Growth Factors. 2012:30:176-191.
20. Yuzhalin AE, Kutikhin AG. Interleukin-12: clinical usage and molecular markers of cancer susceptibility. Growth Factors. 2012;30:176-191.

21. Younes A, Pro B, Robertson MJ, Flinn IW, Romaguera JE, Hagemeister F, et al. Phase II clinical trial of interleukin-12 in patients with relapsed and refractory non-Hodgkin's lymphoma and Hodgkin's disease. Clin Cancer Res. 2004;10:5432-5438.

22. Jaiswal PK, Singh V, Srivastava P, Mittal RD. Association of IL-12, IL-18 variants and serum IL-18 with bladder cancer susceptibility in North Indian population. Gene. 2013;19:128-134

23. Chen $X$, Jiang J, Shen H, Hu Z. Genetic susceptibility of cervical cancer. J Biomed Res. 2011;25:155-164.

24. Wei YS, Lan Y, Luo B, Lu D, Nong HB. Association of variants in the interleukin-27 and interleukin-12 gene with nasopharyngeal carcinoma. Mol Carcinog. 2009:48:751-757.

25. Ben Chaaben A, Busson M, Douik H, Boukouaci W, Mamoghli T, Chaouch L, et al. Association of IL-12p40 +1188 A/C polymorphism with nasopharyngeal cancer risk and tumor extension. Tissue Antigens. 2011;78:148-151.

26. Tao YP, Wang WL, Li SY, Zhang J, Shi QZ, Zhao F, et al. Associations between polymorphisms in IL-12A, IL-12B, IL-12Rß1, IL-27 gene and serum levels of IL-12p40, IL-27p28 with esophageal cancer. J Cancer Res Clin Oncol. 2012;138:1891-1900

27. Eirís N, González-Lara L, Santos-Juanes J, Queiro R, Coto E, Coto-Segura P. Genetic variation at IL12B, IL23R and IL23A is associated with psoriasis severity, psoriatic arthritis and type 2 diabetes mellitus. J Dermatol Sci. 2014;75:167-172

28. Charbonneau B, Maurer MJ, Ansell SM, Slager SL, Fredericksen ZS, Ziesmer SC, et al. Pretreatment circulating serum cytokines associated with follicular and diffuse large B-cell lymphoma: a clinic-based case-control study. Cytokine. 2012;60:882-889.

29. Wang J, Nong L, Wei Y, Qin S, Zhou Y, Tang Y. Association of Interleukin-12 Polymorphisms and Serum IL-12p40 Levels with Osteosarcoma Risk. DNA Cell Biol. 2013;32:1-6.

30. Ling P, Gately MK, Gubler U, Stern AS, Lin P, Hollfelder K, et al. Human $\mathrm{IL}-12 \mathrm{p} 40$ homodimer binds to the $\mathrm{IL}-12$ receptor but does not mediate biologic activity. J Immunol. 1995;154:116-127.

31. Wong RH, Wei JC, Huang $\mathrm{CH}$, Lee HS, Chiou SY, Lin SH, et al. Association of IL-12B genetic polymorphism with the susceptibility and disease severity of ankylosing spondylitis. J Rheumatol. 2012;39:135-140.

32. Ognjanovic S, Yuan JM, Chaptman AK, Fan Y, Yu MC. Genetic polymorphisms in the cytokine genes and risk of hepatocellular carcinoma in low-risk nonAsians of USA. Carcinogenesis. 2009;30:758-762.

33. Ma X, Yan W, Zheng H, Du Q, Zhang L, Ban Y, et al. Regulation of IL-10 and $\mathrm{IL}-12$ production and function in macrophages and dendritic cells. F1000 Faculty Rev. 2015:4:1465.

34. Yang Z, Liang Y, Qin B, Zhong R. Meta-analysis of the association between the IL-12B $+1188 \mathrm{~A} / \mathrm{C}$ polymorphism and cancer risk. Onkologie. 2013:36:470-475

35. Peresi E, Oliveira LR, da Siva WL, da Costa EAP, Araujo JP, Ayres JA, et al. Cytokine polymorphisms: their influence and levels in Brazilian patients with pulmonary tuberculosis during antituberculosis treatment. Tuberc Res Treat. 2013; 2013:285094.

36. Tugues S, Burkhard SH, Ohs I, Vrohlings M, Nussbaum K, Vom Berg J, et al. New insights into IL-12-mediated tumor suppression. Cell Death Differ. 2015;22:237-246 
37. Spachacz R, Kasprzak A, Stefańska K, Trejster E, Seidel J, Zabel M. Tissue expression of cytokines (IL-1alpha, IL-2, IL-6, IL-12, TNF-alpha) in B-cell lymphomas in children. Folia Morphol. 2003;62:483-484.

38. Teng MW, Bowman EP, McElwee JJ, Smyth MJ, Casanova JL, Cooper AM, et al. IL-12 and IL-23 cytokines: from discovery to targeted therapies for immune-mediated inflammatory diseases. Nat Med. 2015;21:719-729.

39. Seegers D, Zwiers A, Strober W, Pena AS, Bouma GA. Taql polymorphism in the $3^{\prime}$ UTR of the IL-12 p40 gene correlates with increased IL-12 secretion. Genes Immunol. 2002:3:419-423.

40. Matoulkova E, Michalova E, Vojtesek B, Hrstka R. The role of the $3^{\prime}$ untranslated region in post-transcriptional regulation of protein expression in mammalian cells. RNA Biol. 2012;9:563-576.

41. Kaarvatn MH, Vrbanec J, Kulic A, Knezevic J, Petricevic B, Balen S, et al. Single nucleotide polymorphism in the interleukin 12B gene is associated with risk for breast cancer development. Scand J Immunol. 2012;76:329-335.

42. Litjens NH, van der Plas MJ, Ravensbergen B, Numan-Ruberg SC, van Assen $Y$, Thio HB, et al. Psoriasis is not associated with IL-12p70/IL-12p40 production and IL12B promoter polymorphism. J Invest Dermatol. 2004;122:923-926

43. Abbas, AK, Lichtman AH, Pillai S. Cellular and molecular immunology. Philadelphia, PA: Elsevier. 2011.
44. Shimozato SI, Ugai, M, Chiyo M, Takenobu H, Nagakawa H, Wada A, et al. The secreted form of the p40 subunit of interleukin (IL)-12 inhibits IL-23 functions and abrogates IL-23-mediated antitumour effects. Immunol. 2006;117:22-28.

45. Uhlig HH, McKenzie BS, Hue S, Thompson C, Joyce-Shaikh B, Stepankova R, et al. Differential activity of IL-12 and IL-23 in mucosal and systemic innate immune pathology. Immunity. 2006;25:309-318.

46. Lu T, Yu S, Liu Y, Yin C, Ye J, Liu Z, et al. Aberrant Circulating Th17 Cells in Patients with B-Cell Non-Hodgkin's Lymphoma. PLoS ONE. 2016;11:e0148044.

47. Jones EA, Pringle JH, Angel CA, Rees RC. Th1/Th2 cytokine expression and its relationship with tumor growth in B cell non-Hodgkin's lymphoma (NHL). Leuk Lymphoma. 2002;43:1313-1321.

48. Klinke DJ. A multiscale systems perspective on cancer, immunotherapy, and Interleukin-12. Mol Cancer. 2010:9:242.

49. Youssef SS, Mohammad MM, Ezz-El-Arab LR. Clinical significance of serum II-12 level in patients with early breast carcinoma and its correlation with other tumor markers. Macedonian J Med Sci. 2015;3:640-644.

50. Zhu KJ, Zhu CY, Shi G, Fan YM. Meta-analysis of IL-12B polymorphisms (rs3212227, rs6887695) with psoriasis and psoriatic arthritis. Rheumatol Int 2013;33:1785-1790

This work is licensed under a Creative Commons Attribution-NonCommercial 3.0 Unported License which allows users to read, copy, distribute and make derivative works for non-commercial purposes from the material, as long as the author of the original work is cited properly. 